\begin{tabular}{lccc} 
VERSITA & GOSPODARKA & SUROWCAMI & MINERALNYMI \\
\hline \multirow{2}{*}{ Tom 29} & 2013 & Zeszyt 3 \\
& & \\
& DOI 10.2478/gospo-2013-0028 &
\end{tabular}

\title{
Magnesite industry in the Slovak Republic
}

\section{Introduction}

Global production of magnesite clinker, caustic magnesite, and fused magnesite totals up to 8 million tonnes per year (Kendall 1996).

During the last 5 years world production has decreased aproximately $20 \%$. This was caused mainly by a decrease in the specific needs for refractory products in the main areas of consumption, the steel and cement industry. Despite the increase in total world steel production, the reduced demand for refractory materials has led to their lower production.

Magnesite producers ultimately realize the exploitation of magnesite raw material through its firing in rotary and shaft kilns and final processing into magnesite building material. This production process, however, leads to pollution of the natural environment. Over the course of more than 30 years, emissions from these production companies have become a severe ecological detriment. Moreover, the state of the environment in individual territories is differentiated (Škvareková, Kozáková 2012).

The basic emmision is magnesite dust (approximately $1 \mathrm{~mm}$ ) with $\mathrm{MgO}$ content of $65-85 \%$, where $\mathrm{MgO}$ is in oxide form or carbonate form. Such environmentally loaded segments have been found at various distances from the source mainly in two settings, agricultural areas and forests. Examinations were conducted according to their weight and according to air conditions.

* Prof., ** Assoc. Prof., ***Assoc. Prof., Technical University of Košice, Faculty of Mining, Ecology, Process Control and Geotechnology, Slovac Republic;

e-mail: adriana.csikosova@tuke.sk, katarina.culkova@tuke.sk,maria.antosova@tuke.sk 
Magnesite emissions result in chemical and mineralogical changes through input into the soil. As the content of magnesite in the soil increases, agrochemical and pedological characteristics of contaminated soil change as well.

Contaminated soil is alkalized; the content of carbon is increasing in addition to the value of $\mathrm{pH}$ from 7-9 based on the change in contamination. Contamination of magnesite compounds is highest in the arable level of soil, but with increasing depth it is decreasing. In more polluted areas, there is creating magnesite material as last level of contamination. Soil in more hilly terrain suffers under greater levels of water erosion.

\section{History of the Slovak magnesite industry and its position on world markets}

The beginnings of the industrial extraction of magnesite in Slovakia date back to 1900 with the construction of two plants in Hačava and Jelšava-Teplá Voda. In 1909, the first rotary kiln was installed for magnesite clinkering with an output of 20,000 tonnes. The magnesite bed with a carboniferous layer was initially opened as an open-cast quarry.

The Hačava plant was supplied with magnesite from deposits at Burda and in Sušiany. Magnesite meeting the needs of the old plant in Jelšava was exploited in various parts of Dúbrava hill. The lower magnesite plant in Hnúšt’a was constructed directly at the site of the Mútnik deposit, and since 1910 it also owned mining rights to the Ružiná deposit.

The Lubeník Chyžná Voda plant started construction in 1906. It consisted of 6 double stool shaft kilns heated with generator gas. For further enrichment of the clinker burnt in shaft kilns, an electromagnetic dressing was installed. In this way, the complex technological chain for magnesite clinker production originated (Gulyás et al. 1986).

In 1923 construction began on a plant at Lovinobaňa. The plant at Lovinobaňa was the only plant in Slovakia with a closed production cycle. Production of burnt magnesite in 1939 totalled 28,800 tonnes. Rising demand for magnesite products led to new investments. In 1942 construction was started on the ninth shaft kiln (Markovič, Balog 1993).

Due to national decree No 100/1945 and the Ministry of Industry's nationalization of individual entrepreneurial companies, the Slovak Magnesite Works (SMZ) was established, a national enterprise centered in Bratislava. Activity of the SMZ enterprise was defined by the Ministry of Industry as follows: "mining, processing, production, distribution of magnesite, dolomite, other materials, products, and semi products where the principal raw material is magnesite, and also performance of other enterprises where connected with the national enterprise."

The national enterprise SMZ had at the time of its origin the following plants and production capacities: the production unit in Lovinobaňa with plants Lovinobaňa, Ružiná, Kalinovo (with mines Jelačič and Poltár); the production unit in Hačava with plants Hačava, Ploské, Sirk, Hnúšta, Ratkovská Suchá; the production unit in Košice with the Košice plant and Košice mine; and the production unit in Jelšava with plants Teplá Voda, Dúbrava, Lubeník, and Ochtiná. 
By establishing the national enterprise SMZ, all magnesite plants came under joint management. The strength of this economic unit was magnified by the fact that it also included plants producing refractories.

In 1946, SMZ started the preparation of investments for a new plant that would produce building materials in Banská Belá.

According to law No 114/1948 regarding the nationalization of several other enterprises, 14 objects were added to the SMZ. The deposit of magnesite in Košice, belonging to the Veitscher Magnesitwerke A.G. in Vienna, was nationalized in 1955, together with another deposit in the area of Podrečany in 1956. The majority of objects remained in SMZ, but some of them were separated; for example the plant Hnúšt’a was added to the enterprise Rudné Bane Banská Bystrica (Gulyas et al. 1986; Markovič, Balog 1993).

In the period from 1949-1970, owing to extensive investments in the construction of the national enterprise SMZ, new plants were built and existing plants were reconstructed. This was a period of extensive development, since mining was recognized as one of the most asset intensive areas of economic activity (Franik 2012). The years 1971-1975 represented a period of intensive development. Investments were made to modernize production and for innovation, with an emphasis on production quality as well as conserving fuel, metal, and energy.

With respect to the development of production capacity, in 1985-1989 a new facility for the production of ironless clinker was built in Hačava which resulted in increased capacity of 26,000 tonnes by 1990 . Realization of a new facility for Special Ceramics Service in Lovinobaňa, with a capacity 35,800 tonnes of building materials, took place from 1986-1990. From 1987-1998 the new shaft kiln No. 1 in Jelšava was built with a capacity of 45,000 tonnes of briquette clinker. In 1995 in Jelšava, construction of the new shaft kiln No. 2 was realized with a capacity of 45,000 tonnes of spinel bearing clinker.

These activities had to guarantee the development of the Slovak magnesite plant. As a consequence of the changes in 1989, there was transformation of the enterprise to the state enterprise, and consequently the enterprise was closed in 1 January 1993. The former SMZ was separated to 8 individual enterprises (Košice, Banská Belá, Hačava, Jelšava, Kalinovo, Lubeník, Lovinobaňa, and Kunová Teplica). From these enterprises the following individual companies were established:

1. Košice magnesite, state enterprise.

2. Slovmag Lubeník, joint stock company.

3. Magnatech Slovakia, Ltd., Hačava.

4. Lovinit, joint stock company, Lovinobaňa.

5. SMZ, joint stock company, Jelšava.

The newly independent companies had to adapt to new circumstances. The situation on the market for refractory material demanded a change in supply that also required a very decisive increase in the quality of the produced assortment and the expantion of the supply to include new materials and products on the market. 
The joint stock company KOMAG, Košice, was established on January $1^{\text {st }}, 1996$. It became the new owner of the Košice magnesite plant. The main tasks of the new company were to maintain mining and processing of the magnesite in Košice, to finish the processing plant in Bočiar, to decrease ecological pollution affecting the city of Košice, to begin and maintain production at the projected capacities, and later to increase employment in the region. Business activities of the company in 1998 were focused on 6 main areas:

1. Sale of caustic magnesite.

2. Sale of floated magnesite clinker.

3. Sale of briquette clinker.

4. Sale of refractory materials.

5. Sale of magnesite sand.

6. Services.

The performance and improvement of all activities were in great measure influenced by the unfavorable financial situation and late influx of credit sources. The company therefore began to experience difficulty in paying its debts. The KOMAG, joint stock company Košice, declared bankruptcy in 1999. In 2001 the Regional Court in Kosice declared covenant of the sale with two subjects. They were presented with company SMZ, joint stock Company, Jelšava; and Teleservis, Ltd. Bratislava (Csikósová, Kameníková 2002).

In 2004, three new joint stock companies were founded. The foundation of the joint stock company SMZ - REVIMEX with its office in Revúca made it possible to take charge of the complete business with Ukraine and Russia. In this way, business operations in this territory have been consolidated, reflecting the needs of the market economy. The company was founded by SMZ, joint stock Jelšava and MIDLAND RESOURCES Holding Ltd., Guernsey. Another new company is the joint stock company KOMATEQ, created by SMZ, joint stock Jelšava and the Swiss company Steinbock Bauxit \& Logistik Chur, conducting operations in China.

The Slovak Republic is an important producer of natural magnesite, with 1,200 thousand tonnes of exploited raw magnesite being $11.4 \%$ of global production. Slovak magnesite with its geological reserves of raw magnesite totalling 734 million tonnes represents $5 \%$ of the global production of magnesite clinker. The percentage share of clinker on the European market is $11 \%$.

In 1998, 1,572.8 thousand tonnes of boose have been exploited and 877.8 thousand tonnes of concentrates have been produced. Magnesite exploitation decreased in comparison to 1997 about 7.9 thousand tonnes, while concentrate production increased about 10.3 thousand tonnes. In comparison to 1993, exploitation of magnesite increased and stabilized (Fig. 1 and 2).

Development in later periods is characterized in Tables 1,2,3. Table 1 shows development of employment levels during the period 1998-2010 at individual magnesite plants in Slovakia dealing with magnesite mining, comparing conditions before and after privatization. In many plants the number of employees decreased due to the privatization. Table 2 illustrates the development of magnesite mining volume in the same period, showing 


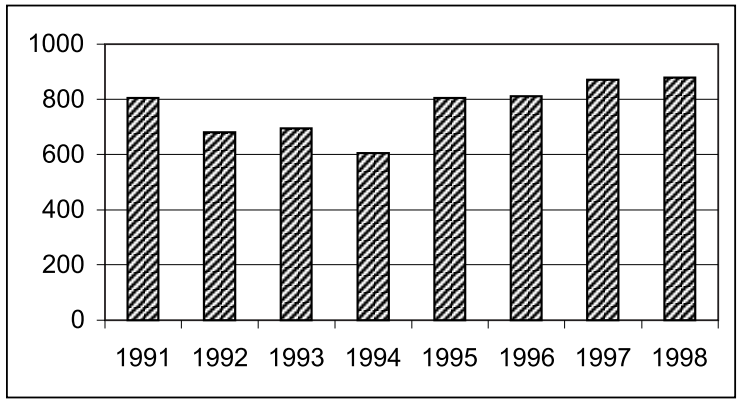

Fig. 1. Development of the magnesite exploitation (thousand tonnes) 1991-1998

Rys. 1. Rozwój wydobycia magnezytu w latach 1991-1998 [tys. ton]

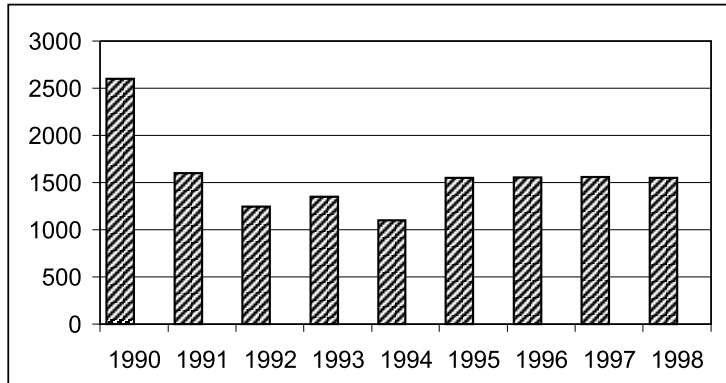

Fig. 2. Development of the magnesite concentrate production (thousand tonnes) 1990-1998

Rys. 2. Rozwój produkcji koncentratów magnezytu w latach 1990-1998 [tys. ton]

that all magnesite plants recorded a decrease in the magnesite volume mined. Table 3 also illustrates decreasing concentrate production during the analyzed period.

From the decade 2000-2010, the most critical year for magnesite companies in Slovakia was 2009, when companies recorded low demand for their products caused by the impact of the economic crisis in the steel industry (on average about 33\%), as well as by growth in energy prices (approximately 4\%). After the adoption of anti crisis measures, magnesite companies succeeded in overcoming the negative developments, and in 2011 they recorded repeated growth in demand and production.

The Slovak magnesite industry is decisively export orientated. The export of individual enterprises' production amounts to $60-90 \%$. Recently the products have been exported mainly to the Czech Republic, Germany, Italy, France, China, India, Cuba, Canada, the U.S.A, Iran, South Africa, Austria, Slovenia, and Ukraine. This heavy focus on exports increases requirements for the products to be competitive concerning their quality and price. According to Krzak (2012, p. 25), the quality of natural resources, including magnesite, is to be maintained over the long term. Slovak producers are in a difficult situation since young Slovak private firms face competition from strong multinational corporations mainly from Austria and Germany. 


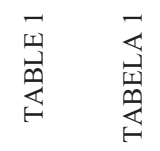

\begin{tabular}{|c|c|c|c|c|c|c|}
\hline 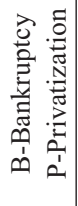 & 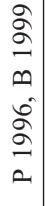 & $\left|\begin{array}{l} \pm \\
\partial \\
2 \\
2\end{array}\right|$ & $\begin{array}{l}\Delta \\
\sigma \\
a \\
a\end{array}$ & & $\frac{\circ}{2}$ & \\
\hline$\stackrel{\infty}{2}$ & ๙ิ & $\begin{array}{c}\stackrel{7}{2} \\
\end{array}$ & $\overparen{\lambda}$ & 0 & $\because$ & $\begin{array}{l}\hat{\delta} \\
\dot{0} \\
N\end{array}$ \\
\hline ڤे & 今్ & $\begin{array}{c}a \\
\infty \\
n \\
-2\end{array}$ & $\stackrel{\mathcal{N}}{\mathrm{f}}$ & 0 & $\stackrel{\bullet}{\circ}$ & $\frac{\tilde{m}}{\sim}$ \\
\hline ڤ్రి & 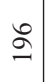 & $\begin{array}{c}2 \\
\mathfrak{b} \\
-\end{array}$ & $\stackrel{\infty}{\stackrel{\infty}{-}}$ & 0 & 0 & $\begin{array}{l}\text { } \\
\text { े } \\
\text { r }\end{array}$ \\
\hline 完 & 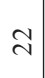 & $\hat{\tilde{2}}$ & $\underset{\sim}{\infty}$ & 0 & 0 & $\begin{array}{l}\hat{\delta} \\
\text { సे }\end{array}$ \\
\hline ڤેे & $\approx$ & 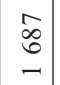 & $\stackrel{\mathrm{N}}{\mathrm{d}}$ & 0 & 10 & $\vec{a}$ \\
\hline ڤ్రి & $\stackrel{\infty}{=}$ & $\begin{array}{l}\vec{b} \\
i\end{array}$ & $\stackrel{\mathrm{N}}{\mathrm{N}}$ & ה & 10 & $\begin{array}{l}0 \\
\infty \\
\infty\end{array}$ \\
\hline 总 & $\stackrel{\infty}{\sim}$ & $\mid \begin{array}{c}\stackrel{\otimes}{ \pm} \\
\underset{-}{2}\end{array}$ & ) & i & 10 & $\begin{array}{l}\infty \\
\stackrel{\infty}{\simeq}\end{array}$ \\
\hline ڤ્సે & $\vec{v}$ & $\left|\begin{array}{c}\infty \\
\sim \\
\sim\end{array}\right|$ & 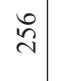 & ते & 0 & $\begin{array}{l}\mathbf{D} \\
\text { ర్ }\end{array}$ \\
\hline ¿্ণ & $\stackrel{\sim}{\infty}$ & $\frac{n}{m}$ & 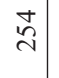 & f & 0 & బ్ర \\
\hline ¿্స & $\stackrel{\sim}{2}$ & $\begin{array}{l}\Xi \\
=\end{array}$ & $\begin{array}{l} \pm \\
m\end{array}$ & ले & 0 & $\begin{array}{l}0 \\
i n \\
-1\end{array}$ \\
\hline $\begin{array}{l}\infty \\
\stackrel{\text { ¿े }}{0}\end{array}$ & $m$ & 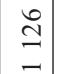 & $\vec{m}$ & 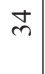 & 0 & ஓ্ \\
\hline ¿্ণ & 0 & $\begin{array}{l}\infty \\
\infty \\
\infty\end{array} \mid$ & $\stackrel{\infty}{\sim}$ & $\hat{\sim}$ & 0 & $\hat{0}$ \\
\hline$\overline{\text { ते }}$ & 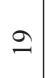 & $\stackrel{\infty}{\infty}$ & 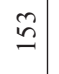 & $\stackrel{m}{m}$ & 0 & $\tilde{\sigma}$ \\
\hline & 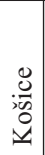 & 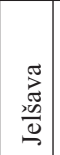 & 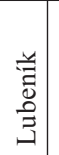 & $\begin{array}{l}\text { 苟 } \\
\text { 总 }\end{array}$ & $\mid$ & 竞 \\
\hline
\end{tabular}

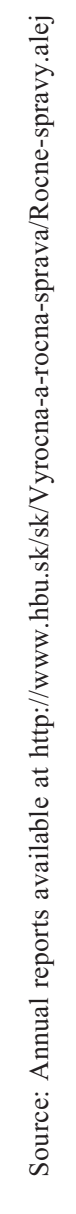




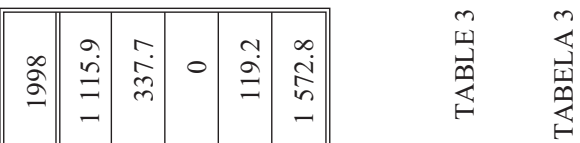

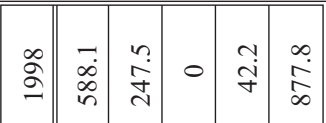

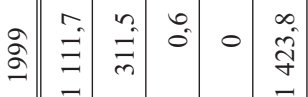

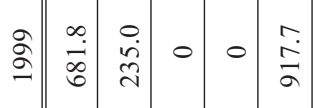

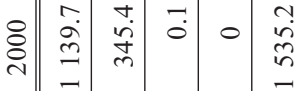

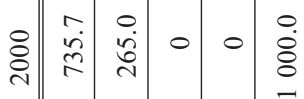

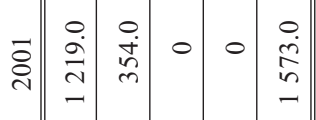

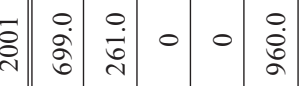

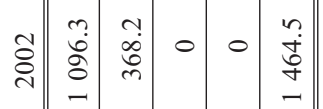

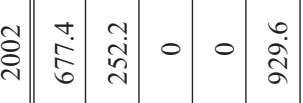

$\Phi$

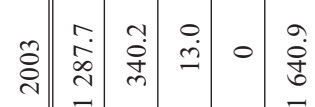

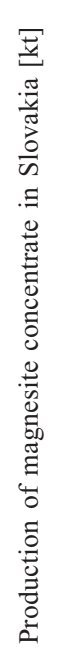

\begin{tabular}{|c|c|c|c|c|c|}
\hline & & fo & $\overrightarrow{\dot{d}}$ & 0 & 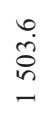 \\
\hline$S_{v}$ & 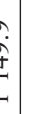 & $\begin{array}{c}0 \\
\mathbf{v} \\
\end{array}$ & $\stackrel{0}{\circ}$ & 0 & \begin{tabular}{l}
$\infty$ \\
$⿱$ \\
\hdashline
\end{tabular} \\
\hline 0 & $\frac{1}{5}$ & $\stackrel{d}{s}$ & $\stackrel{0}{\dot{b}}$ & 0 & $\begin{array}{l}0 \\
\dot{0} \\
\infty\end{array}$ \\
\hline 帘 & $\frac{f}{b}$ & 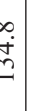 & $\stackrel{\Delta}{\sigma}$ & 0 & $\begin{array}{l}n \\
\stackrel{\sim}{\beth}\end{array}$ \\
\hline & 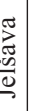 & & 溁 & & \\
\hline
\end{tabular}

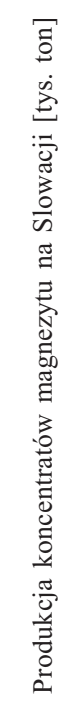

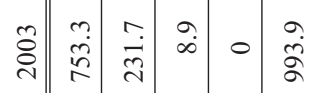

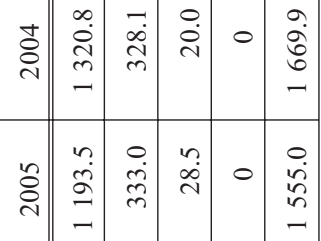

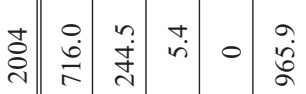

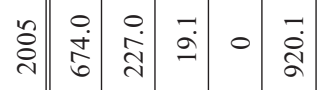

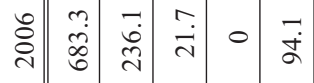

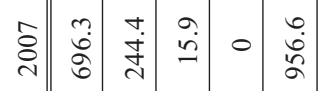

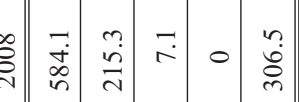

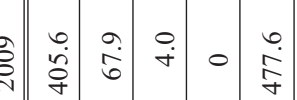

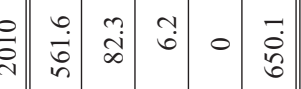

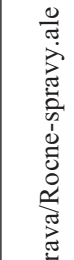

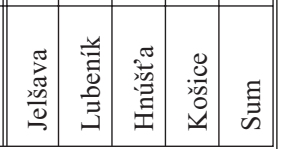


Grades and specifications for selected caustic-calcined, dead-burned magnesias

TABELA 4

Gatunki i specyfikacja jakościowa wybranych magnezytów kalcynowanych i prażonych

\begin{tabular}{|c|c|c|c|c|c|c|c|}
\hline $\begin{array}{c}\text { Material and Source } \\
\text { Country }\end{array}$ & $\begin{array}{c}\mathrm{MgO} \\
{[\%]}\end{array}$ & $\begin{array}{c}\mathrm{SiO}_{2} \\
{[\%]}\end{array}$ & $\begin{array}{l}\mathrm{CaO} \\
{[\%]}\end{array}$ & $\begin{array}{c}\mathrm{Fe}_{2} \mathrm{O}_{3} \\
{[\%]}\end{array}$ & $\begin{array}{c}\mathrm{Al}_{2} \mathrm{O}_{3} \\
{[\%]}\end{array}$ & $\begin{array}{c}\mathrm{B}_{2} \mathrm{O}_{3} \\
{[\%]}\end{array}$ & $\begin{array}{l}\text { Density } \\
{\left[\mathrm{g} / \mathrm{cm}^{3}\right]}\end{array}$ \\
\hline \multicolumn{8}{|c|}{ Caustic - calcined magnesia } \\
\hline Canada & 96.3 & 0.4 & 2.7 & 0.5 & 0.1 & na & NA \\
\hline Slovakia & 78.0 & 1.0 & 2.5 & 7.0 & 0.0 & na & NA \\
\hline Spain & 85.0 & 3.6 & 7.0 & 2.5 & 0.4 & na & NA \\
\hline United States (brine) & 97.0 & 0.5 & 1.0 & 0.3 & 0.2 & na & NA \\
\hline United States (seawater) & 97.2 & 0.4 & 0.9 & 0.24 & 0.28 & NA & NA \\
\hline \multicolumn{8}{|c|}{ Dead burned magnesia } \\
\hline Australia & 97.0 & 0.5 & 2.3 & 0.1 & 0.1 & na & 3.42 \\
\hline Brazil & $94.9-98.4$ & $0.25-1.29$ & $0.43-0.77$ & $0.41-2.11$ & $0.05-0.35$ & 0.007 & $3.07-3.34$ \\
\hline China (DBM 9010) & 91.3 & 4.0 & 2.3 & 1.2 & 1.2 & na & 3.2 \\
\hline China (DBM 95) & 95.4 & 2.2 & 1.6 & 1.0 & 1.0 & na & 3.2 \\
\hline China (DBM 97) & 97.3 & 0.7 & 1.4 & 0.8 & 0.2 & na & 3.3 \\
\hline Greece & $85-96$ & $1.1-9.0$ & $1.5-3.5$ & $0.15-0.7$ & NA & na & $3.15-3.4$ \\
\hline India & $>93.0$ & 4.5 & 1.2 & 1.0 & 0.8 & na & 3.2 \\
\hline Iran & 96.0 & 1.7 & 1.1 & 0.25 & 0.45 & na & 3.4 \\
\hline Ireland & 97.2 & 0.25 & 2.1 & 0.2 & 0.07 & $0.01-0.02$ & 3.43 \\
\hline Israel & 99.3 & 0.03 & 0.63 & $0.04-0.07$ & 0.03 & 0.005 & $3.43-3.45$ \\
\hline Italy & 97.3 & 0.5 & 2.1 & 0.1 & 0.15 & 0.060 & 3.46 \\
\hline Japan & 98.1 & 0.36 & 1.3 & 0.05 & 0.06 & na & 3.48 \\
\hline Mexico & 98.7 & 0.2 & 0.87 & 0.12 & 0.15 & 0.01 & 3.43 \\
\hline Netherlands & 98.5 & 0.12 & 0.74 & 0.44 & 0.07 & 0.01 & 3.4 \\
\hline North Korea & 91.9 & 4.0 & 1.8 & 1.1 & 0.7 & na & 3.2 \\
\hline Serbia and Montenegro & $85-96$ & $1.0-5.0$ & $2.0-5.5$ & $0.6-3.5$ & $0.3-1.3$ & na & $3.51-3.55$ \\
\hline Slovakia & $87-90$ & $0.7-3.5$ & $2.0-2.5$ & $4.7-7.5$ & $0.3-0.8$ & na & $3.2-3.35$ \\
\hline Turkey & $89-97$ & $0.6-6.0$ & $1.7-3.0$ & $0.4-1.2$ & $0.1-0.2$ & na & $3.3-3.45$ \\
\hline United States & $97.9-98.4$ & $0.25-0.85$ & $0.85-1.05$ & $0.14-0.2$ & $0.12-0.19$ & $0.024-0.064$ & $3.15-3.38$ \\
\hline
\end{tabular}

na - not applicable

NA - not available

Source: Ó Driscoll 2003a, b, c 
The steel industry is the biggest consumer of basic refractory products. The product portfolio for this industry includes magnesia, magnesia-chromite, and magnesia-carbon shaped products-bricks. According to customers' needs the bricks are supplemented by unshaped products-ramming mixes, gunning mixes, filling mixes, repairing mixes, and mortars. These products are used in the safety and working linings of oxygen converters, electric arc furnaces, ladles, and vessels of secondary metallurgy.

Bricks and mortars are used for copper, lead, zinc, and nickel heat aggregates production. They can be used in anode furnaces, converters, drum furnaces, flash smelting furnaces, etc. Basic refractory products for this segment are available in rotary and shaft kilns. Various shapes and qualities enable the making of linings for particular thermal zones and technological conditions. The high specific heat capacity of magnesia can be utilized in block storage heaters production for a heat accumulation until its effective consumption. Variously shaped products based on sintered magnesia and olivine can be used.

The global perspective on magnesite quality is also a determining factor for realization on the market. All new deposits in the world have $92-98 \%$ content of MgO. Table 4 indicates the qualitative classification of Slovak magnesite clinker.

The review demonstrates that Slovak magnesite clinker is classified in the lowest quality class due to its $8-9 \%$ content of $\mathrm{Fe}_{2} \mathrm{O}_{3}$. Magnesite of ideal quality should have $\mathrm{Fe}_{2} \mathrm{O}_{3}$ content not exceeding 1\%. The content of $\mathrm{Fe}_{2} \mathrm{O}_{3}$ in combination with $\mathrm{CaO}$ also present in Slovak natural magnesite causes a decisive decrease in the fireproofing ability of the clinker and thus also building materials produced from such clinkers (Csikósová et al. 2000).

\section{Influence of Slovak magnesite production on the environment and related environmental protection aspects}

All processes realized by magnesite companies, i.e. exploitation of magnesite, its processing, firing in rotary and shaft kilns, and production of magnesite refractory material, cause pollution of the natural environment. Over a period of more than 100 years, the emissions from such companies have caused severe ecological harm.

For several years the dust deposition in areas surrounding magnesite processing plants exceeded the values of maximum allowable concentration (MAC), i.e. 150 t.km ${ }^{-2}$, or $12.5 \mathrm{~g} \cdot \mathrm{m}^{-2}(30 \text { days })^{-1}$, and with a composition and $\mathrm{MgO}$ content of $30-40 \%$ it contaminated a wider area of local plantlife. In the 1970s in the vicinity of the most concentrated production, i.e. the Lubeník-Jelšava belt, the MAC was exceeded in an area of $32 \mathrm{~km}^{2}$ (Leško, Bobro 1987).

The average chemical composition of solid dust outlets from rotary kilns of operating magnesite plants is presented in Table 5 (Bobro, Hančulák 2001).

The elements shown in Table 5 contaminate the soil through the air in the form of dust containing mineral phases. The dominant minerals in dust emmisions consist of periclase and caustic $\mathrm{MgO}$ that are accompanied by magnesite, calcite, as well as dolomite. 
Content of elements in dust outlets from rotary kilns of magnesite processing plants $\left[\mathrm{mg} \cdot \mathrm{kg}^{-1}\right.$ ]

TABELA 5

Zawartość pierwiastków w pyłach odlotowych z pieców obrotowych w zakładach przetwórstwa magnezytów $\left[\mathrm{mg} \cdot \mathrm{kg}^{-1}\right]$

\begin{tabular}{|c|c|c|c||}
\hline Plant & Jelšava & Lubeník & Bočiar \\
\hline \hline $\mathrm{Mg}$ & 332,600 & 267,000 & 422,300 \\
\hline $\mathrm{Ca}$ & 9,730 & 11,400 & 10,400 \\
\hline $\mathrm{Fe}$ & 46,250 & 15,800 & 38,300 \\
\hline $\mathrm{Mn}$ & 2,270 & 1,222 & 2,800 \\
\hline $\mathrm{Cu}$ & 20 & 17 & 55 \\
\hline $\mathrm{Pb}$ & 14 & 10 & 19 \\
\hline $\mathrm{Zr}$ & 47 & 40 & 95 \\
\hline $\mathrm{Co}$ & 4 & 26 & 98 \\
\hline $\mathrm{Cr}$ & 22 & 33 & 64 \\
\hline $\mathrm{Ni}$ & 87 & 54 & 6 \\
\hline $\mathrm{As}$ & 0.6 & 27 & 0.8 \\
\hline $\mathrm{Hg}$ & 7 & 0.4 & 2 \\
\hline $\mathrm{Cd}$ & 6 & 1 & 99 \\
\hline $\mathrm{Sb}$ & & & 99 \\
\hline
\end{tabular}

The mineral composition of polluted areas where magnesite deposits occur and processing facilities were and are in operation, including their history and influences on the environment, are discussed below.

Localities in Slovakia featuring the presence of magnesite industry, specifically the soils and their dynamic components such as soil reaction, nutrients regime, biological activity, organic substances quality, and structural status of the plough layer, are still influenced by $\mathrm{Mg}$ emissions. According to agrochemical criteria, the acceptable amount of $\mathrm{Mg}$ received by soil is up to $200 \mathrm{mg} \cdot \mathrm{kg}^{-1}$. But in the localities with magnesite industry this value is exceeded by 4-100 fold. Under natural conditions the annual loss of magnesium per one hectare of soil by crops, leaching, and migration amounts to 26-34 kg (Hronec 1996).

Thus, it is possible to decrease the $\mathrm{Mg}$ content in soil during a determinated period, assuming its continued input is stopped. Currently, however, in the surroundings of magnesite plants the input of $\mathrm{Mg}$-bearing dust into soil continues. For instance, dust emmisions from Lubeník contain $44.5 \% \mathrm{MgO}$, in Jelšava $55.4 \% \mathrm{MgO}$, and in the former magnesite processing plant in Košice $77 \% \mathrm{MgO}$. 


\subsection{Lovinobaňa deposit}

Magnesite at the Lovinobaňa deposit has been processed in shaft kilns. A favorable localization of the magnesite plant with regard to the morphology of the surrounding terrain, where a valley widens towards the south and the prevailing air current is in the direction of NNW-SSE, did not create any conditions enabling the contamination of the wider surroundings. The soils were contaminated in the direction of prevailing wind to a distance of about $2 \mathrm{~km}$. Crusts were not observed beyond the plant area. The following minerals were determined in the crusts: periclase $(\mathrm{MgO})$, magnesite, dolomite, calcite, hydromagnesite, brucite, and hydrocalcite. The dominant mineral was caustic $\mathrm{MgO}$, from which secondary minerals originated. These minerals are soluble in weak acids, and this fact results in the movement of their dissolved components into deeper parts of soil horizon. Recently, thermal technological centers of the plant do not operate; thus, conditions are favorable for environmental regeneration.

\subsection{Mútnik and Hačava deposits}

The raw-material was initially processed in shaft kilns in Hačava, and in the 1960s a rotary kiln was put into operation. Unfavorable morphology of the surrounding terrain, technologies removing dust, and the other operating plants in vicinity caused intensive devastation of the landscape. A coherent crust with an area of several tens of hectares without vegetative cover was formed. The crust is composed of primary dust particles that are cemented by secondary minerals. Caustic $\mathrm{MgO}$ and periclase are present as the dominant minerals. The secondary minerals are comprised of brucite, hydromagnesite, and hydrocalcite. Later, these minerals with water in their structure crystallized into calcite and dolomite. This resulted in a crust which is stony and resiliant. The content of $\mathrm{MgO}$ in the crust reaches $55-60 \%$. The crust is slowly disintegrating due to the deactivation of the plants.

\subsection{Jeľsava and Lubeník deposits}

Initially, magnesite was processed in shaft kilns, later in annular kilns, and finally for the last 30 years in rotary kilns. Recently, five shaft and one rotary kiln are working in Lubeník, and three rotary and four shaft kilns are operating in Jelšava. In this area, the processing of magnesite has been a tradition for more than 100 years, and during this period a wide area surrounding these plants was contaminated by the emissions of solid particles. Devices for dust removal were imperfect, and for this reason the crust strongly alkalized soils with similar mineralogical composition as described above. Lastly, a high dust deposition was caused by the application of rotary kilns designed for lime dust outlets but not suitable for the magnesite kilns. This fact resulted in an intensive contamination of a wide surrounding area. The dominant minerals are calcite and dolomite. The area, where two magnesite processing plants operate, can be characterized as a narrow valley lying in a NW-SE direction, closed on its 
sides by mountain massifs. Thus, the prevailing wind is also in the direction of the valley. For this reason, the crust composed from $\mathrm{Mg}$ salts, i.e. primary and secondary minerals of dust emissions, with a thickness up to $5 \mathrm{~cm}$ have been created on the soils in the surroundings of the plants (Markovič, Balog 1993).

Generally crusts originate in cases where dust deposition with $\mathrm{Mg}$ content over 50\% exceeds the amount of $600 \mathrm{t} . \mathrm{km}^{-2}$.year ${ }^{-1}$. The following minerals are present: periclase, caustic $\mathrm{MgO}$, magnesite, dolomite, calcite, and also hydrates of these minerals. Minerals were identified by means of DTA and X-ray analysis (Bobro et al. 2000). Currently, the ecological situation is improving as a result of new, highly effective dust collecting devices installed, namely Amertherm. For instance, from 1970-1980 the emission of solids amounted to about 4,800 t.year ${ }^{-1}$, but in 1990 it was 500 t.year $^{-1}$, and in 2000 it was 170 t.year $^{-1}$ in Jelšava and 85 t.year $^{-1}$ in Lubeník. This view is very optimistic and the situation is improved by the plants' management's serious approach to environmental issues in this damaged area (Hančul'ák 2000, 2001).

The joint-stock companies Jelšava and Lubeník devote particular attention to the field of formation and protection of the environment. No serious problems appeared in 2005. Assessed limits were also observed at the prescribed standards in the areas of atmosphere, water, and waste output. These are the areas that have to be considered priorities from the viewpoint of technology and the consequences of previous years, as they represent highly variable fields. Rotary kilns seemed to be the most problematic sources of atmospheric interference. Behind the third level of the redusting processors, the companies installed a comprehensive automatic system for the measuring of emissions.

\subsection{Košice deposit}

At the start, two shaft kilns were operated at the Košice deposit. In 1950s, the magnesite processing plant was relocated to Ťahanovce, where in the 1980s and 1990s rapid housing development resulted in that plant finding itself in the midst of an urban settlement. Up to 1990, four rotary kilns were in operation there, later reduced to only two which were equipped with the dust collecting system Amertherm. Because the plant was located in the northern part of a densely populated area widening in an E-W direction, while the prevailing air current was in a N-S direction, all agglomerations have been contaminated. After the installation of effective dust collecting devices, the $\mathrm{Mg}$ content in dust deposition fell from $35-40 \%$ to $8-10 \%$, and in aerosol, i.e. in dust ambient, it decreased from $20 \%$ to $1-3 \%$. Today, the plant is not in operation, but all areas of plant and spoil areas are, and will be for a long time, a plane source of mineral dusts. In this locality, the laminate of mineral dust in the form of periclase, magnesite, calcite, and the hydrates of the other carbonates still occur, and during stronger winds they pollute the wider area of the agglomeration. Currently, the magnesite processing plant has been moved to the Bočiar locality near the iron and steel works factory, where applied technologies of dust elimination are almost emission free (Novek et al. 2001). 


\section{Conclusion}

This paper characterizes the development of magnesite processing from a historical perspective together with a summary of the associated technologies available in Slovakia. Specifics of magnesia, including chemical composition, bulk density, particle size, and loss on ignition, are generally set by the consumer for a specific application. Refractory magnesia composition depends on the area of the kiln in which the material is to be used. Dead-burned magnesia from Slovakia supplies the low to medium market. Broad uses include such products in the production of cement building materials, magnesite, and magnesite-chromium refractories, as well as nonworking panels in electric kilns. Magnesite of these qualitative parameters is also elaborated by recent global producers, such as the Veitsch-Radex-Didier firm, Refratechnik, ZM Ropczyce, and ArcelorMittal Refractories Kraków. The deposit exploited by Slovmag Lubeník also belongs to this group. Such building materials have been broadly used for steel production in Siemens-Martin kilns recently being compensated with electrical kilns and convertors. The operating conditions of new equipment require heat resistant materials with a much higher content of $\mathrm{MgO}$. The same trends also exist in the production of cement building materials where clinkers with low iron content, for example the periclase-spinelitical type, are preferable.

The certified system of quality management according ISO 9000 is unambiguous in its demands for facing hard competition. Slovmag Inc. Lubeník and Slovak Magnesite Works JSC Jelšava fulfill such criteria.

Approximately $70 \%$ of the products of the magnesite industry are used in the steel industry, $15 \%$ in the cement industry, and $15 \%$ in the production of nonferrous metals as well as ferroalloy and lime, in glass industry applications, and in the filling of heat-accumulation kilns. Systematic monitoring of the qualitative and quantitative trends in the mentioned industrial operations is a necessary requirement for a proper research and development orientation as well as a successful business. The steel industry is the main consumer of refractory materials; therefore, it is the main target of focused marketing research by Slovak magnesite producers.

Enhanced $\mathrm{Mg}$ content in the air, soil, water, and consequently insignificantly in biomass is a special Slovak problem in localities around magnesite industry. More advanced technologies and feasible management with these valuable raw materials means expectations that the input of magnesium into natural and municipal surroundings will constantly decrease. Technologies without waste are planned in this branch of industry, but this remains a long-term vision. Visible damages as a result of previous operating technologies will endure, and generally improve the situation. 


\section{REFERENCES}

B obro M., Hančul'ák J., 2001 - Influence of Slovak magnesite processing on the environment. Mineralia Slovaca vol. 6, no 33, pp. 535-538.

Csikós ová A., Ka meníková K., 2002 - Economical Evaluation of living environment pollution. Boletin Paranaense de GEO Ciencias, IGCP 443 Magnesite and Talc Geological and Environmental Correlations no 50, pp. 97-104.

C s i kó s o vá A., et al., 2000 - Csikósová A., Novek Z., Kameníková K., 2000 - Position of Slovak magnesite on world markets. Mineralia Slovaca vol. 32, no 6, pp. 530-532.

Franik T., 2012 - Study on factors influencing the level of capital expenditure spent in mining. Gospodarka Surowcami Mineralnymi vol. 28, no 4, pp. 71-86.

Gulyás et al. 1986 - Gulyás T., Frák G., Ilavský R., 1986 - Magnesite industry in Czechoslovakia. Výchoslovenské vydavatel'stvo, n.p. Košice.

H a n č u l'á k J., 2000 - Development of the dust deposition in area of SMZ. Inc. Jelšava Acta Montanistica Slovaca vol. 5, no 3, pp. 310-312.

Ha n č u l'ák J., 2001 - Solid emissions in the area of magnesite industry operation in Jelšava and Lubeník. UGT SAV, Košice.

Hro ne c O., 1996 - Exhalations, soil, vegetation. Monograph TOP, Ltd. Prešov and SPPK Bratislava, p. 236.

Kendal1 T., 1996 - Dead - Burned Magnesite, Industrial Minerals no 341, pp. 25-51.

Krzak M., 2012 - Dilemmas of mineral resources use in selected economic theories. Gospodarka Surowcami Mineralnymi vol. 28, no 3, p. 25

Le šk o O., B o bro M., 1987 - Development of dust deposition in the plants of SMZ Jelšava and SMZ Lubeník. Rudy-uhlí-geologický pruzkum no 8, pp. 232-234.

Markovi č J., B a log J., 1993 - Magnesite Jelšava, Východoslovenské vydavatel'stvo, n. p. Košice.

Novek Z. et al. 2001 - Novek Z., C s ikósová A., Ka meníková K., Hri ci šinová A., 2001 - Historical development of the magnezite plant in Košice. Mineralia Slovaca, vol. 33, no 6, pp. 551-556.

O ’D r i s c o 11 M., 2003a - Back to basics. Industrial Minerals, no 434, pp. 30-43.

O ’D r i s c o 11 M., 2003b - Elements of magnesia. Industrial Minerals, no 431, pp. 44-51.

O 'D ris c oll M., 2003c - In the hall of the magnesite king. Industrial Minerals, no 430, pp. $26-37$.

Skvareková E., Kozakova L., 2012 - Brown coal and lignite issues from the perspective of sustainable development in Slovakia. Gospodarka Surowcami Mineralnymi vol. 28, no 2, pp. 31-42.

www.hbu.sk/sk/Vyrocna-a-rocna-sprava.alej.

\section{PRZEMYSL MAGNEZYTOWY W REPUBLICE SLOWACKIEJ}

\section{Słowa kluczowe}

Zanieczyszczenie, środowisko naturalne, produkty magnezytowe, wydobycie magnezytu, marketing, segmentacja rynku

\section{Streszczenie}

Baza zasobowa magnezytów w Republice Słowackiej sięga 3400 milionów ton magnezytu surowego. Rozpoznane światowe zasoby magnezytu są oceniane na około 12 milardów ton, a poza nimi znane są także wielkie zasoby innych surowców magnezonośnych, takich jak: dolomit, brucyt czy oliwin. Co więcej, związki magnezu mogą być także pozyskiwane w sposób ekonomicznie uzasadniony z solanek metodą ługowania otworowego, z jezior solankowych oraz z wody morskiej. Ta ostatnia zawiera średnio $0,13 \%$ mas. magnezu, będąc znaczącym źródłem związków magnezu. Niniejsza praca miała na celu podanie krótkiej informacji o rozwoju górnictwa i przetwórstwa magnezytu na Słowacji, a także o historii słowackiego przemysłu magnezytowego. 
Artykuł podsumowuje możliwości produkcyjne słowackiego przemysłu magnezytowego oraz możliwości jego utrzymania w świetle silnej konkurencji z innymi światowymi producentami magnezytu. Działalność słowackiego przemysłu magnezytowego, choć przynosi wymierne efekty w postaci produkcji surowców magnezytowych, ma także niekorzystny wpływ na najważniejsze składniki środowiska naturalnego, tj. gleby, wody, atmosferę oraz faunę i florę. Jest on wywołany głównie emisją gazowo-pyłową, przede wszystkim z etapu termicznego przetwórstwa magnezytów surowych. Obecnie wielkość tej emisji została znacząco ograniczona dzięki instalacji odpowiednich filtrów wyłapujących pyły.

\section{MAGNESITE INDUSTRY IN THE SLOVAK REPUBLIC}

$$
\text { Key words }
$$

Pollution, living environment, magnesite products, magnesite exploitation, marketing, market segmentation

\section{Abstract}

The reserve base of magnesite in the Slovak Republic is 3,400 million tonnes of magnesium raw material. Identified world resources of magnesite total some 12 billion tonnes, and there are also large resources of magnesium-bearing substitutes such as dolomite, brucite, and olivine. Furthermore, magnesium compounds can be recovered economically from well and lake brines, and from sea water. The latter, which contains $0.13 \%$ by weight of magnesium, is a major source of this raw material and its compounds. This paper presents a summary of the development of the mining and treating of magnesite in Slovakia and the history of the magnesite industry.

The paper summarizes the production capabilities of the Slovak magnesite industry and its potential for survival in competition with other world producers. The prosperity of the Slovak magnesite industry's exploitation of domestic raw-material resources also has unfavorable influences on the basic components of the environment, i.e. soil, water, and surrounding air and biota. These unfavorable influences are caused by the emissions above all from thermal technologies involved in the processing of magnesite raw-material. At present, the level of emissions is significantly reduced by the installation of dust collecting devices. 
